\title{
Hydrological simulation of a small ungauged agricultural watershed Semrakalwana of Northern India
}

\author{
Himanshu Mishra ${ }^{1}$ - Derrick Mario Denis ${ }^{1} \cdot$ Shakti Suryavanshi $^{2} \cdot$ Mukesh Kumar $^{1}$ • \\ Santosh Kumar Srivastava ${ }^{1}$ Anjelo Francis Denis ${ }^{3} \cdot$ Rajendra Kumar $^{4}$
}

Received: 19 October 2015/Accepted: 11 January 2017/Published online: 10 March 2017

(c) The Author(s) 2017. This article is published with open access at Springerlink.com

\begin{abstract}
A study was conducted to develop a hydrological model for agriculture dominated Semra watershed $\left(4.31 \mathrm{~km}^{2}\right)$ and Semrakalwana village at Allahabad using a semi distributed Soil and Water Assessment Tool (SWAT) model. In model evaluation it was found that the SWAT does not require much calibration, and therefore, can be employed in unguaged watershed. A seasonal (Kharif, Rabi and Zaid seasons) and annual water budget analysis was performed to quantify various components of the hydrologic cycle. The average annual surface runoff varied from 379 to $386 \mathrm{~mm}$ while the evapotranspiration of the village was in the range of $359-364 \mathrm{~mm}$. The average annual percolation and return flow was found to be $265-272 \mathrm{~mm}$ and $147-255 \mathrm{~mm}$, respectively. The initial soil water content of the village was found in the range of $328-335 \mathrm{~mm}$ while the final soil water content was 356-362 mm. The study area fall under a rain-fed river basin (Tons River basin) with no contribution from snowmelt, the winter and summer season is highly affected by less water availability for crops and municipal use. Seasonal (Rabi, Kharif and Zaid crop seasons) and annual
\end{abstract}

Himanshu Mishra

himanshumishra_121@rediffmail.com

1 Department of Soil, Water, Land Engineering and Management, Sam Higginbottom University of Agriculture, Technology and Sciences, Allahabad 211007, Uttar Pradesh, India

2 Department of Civil Engineering, Sam Higginbottom University of Agriculture, Technology and Sciences, Allahabad, Uttar Pradesh, India

3 Department of Agricultural Engineering, NIMS University, Jaipur, Rajasthan, India

4 Uttar Pradesh Council of Agricultural Research, Lucknow, India water budget of Semra watershed and Semrakalwana village evoke the need of conservation structures such as check dams, farm ponds, percolation tank, vegetative barrier, etc. to reduce monsoon runoff and conserve it for basin requirements for winter and summer period.

Keywords Rural watershed - Water balance - SWAT model $\cdot$ Semrakalwana village

\section{Introduction}

Watershed management strategies are vital to efficiently utilize the natural resource as to maintain environmental regime. Watershed models that are capable of capturing hydrological processes in a dynamic manner can be used to provide an enhanced understanding of the relationship between land and water management options. In recent years, hydrologic models are more and more widely applied by hydrologists and resource managers as a tool to understand and manage ecological and human activities that affect watershed systems (Zhang 2009). Several models have been developed [Système Hydrologique Européen (SHE) (Abbott et al. 1986; Bathurst and O'Connell 1992; Refsgaard and Storm 1995), Institute of Hydrology Distributed Model (IHDM) (Beven and Morris 1987) and the THALES (Grayson et al. 1992), Basin Scale Hydrological Model (BSHM) (Yu and Schwartz 1998), Soil and Water Assessment tool (SWAT) (Arnold et al. 1998 , etc.] in the past that can continuously simulate stream flow, erosion or nutrient loss from a watershed (Table 1). One such model is the Soil and Water Assessment Tools (SWAT) model, which is a continuous time model that operates on a daily time step. The objective in model development is to predict the impact of management 
Table 1 List of some available models with their processes

\begin{tabular}{|c|c|c|}
\hline Model name/acronym & Author(s) (year) & Remarks \\
\hline Tennessee Valley Authority (TVA) Model & Tennessee Valley Authority (1972) & Lumped, event-based runoff model \\
\hline Utah State University (USU) Model & Andrews et al. (1978) & $\begin{array}{l}\text { Process-oriented, event/continuous Stream flow } \\
\text { model }\end{array}$ \\
\hline Purdue Model & Huggins and Monke (1970) & $\begin{array}{l}\text { Process-oriented, physically based, event runoff } \\
\text { model }\end{array}$ \\
\hline $\begin{array}{l}\text { Hydrologic Engineering Center-Hydrologic } \\
\text { Modeling System (HEC-HMS) }\end{array}$ & Feldman (1981) and HEC (1981) & $\begin{array}{l}\text { Physically based, semi distributed, event-based, } \\
\text { runoff model }\end{array}$ \\
\hline Storm Water Management Model (SWMM) & $\begin{array}{l}\text { Metcalf and Eddy (1971), Huber and } \\
\text { Dickinson (1988) and Huber (1995) }\end{array}$ & $\begin{array}{l}\text { Process-oriented, semi distributed, continuous storm } \\
\text { flow model }\end{array}$ \\
\hline Hydrological Simulation (HBV) Model & Bergstrom $(1976,1992)$ & $\begin{array}{l}\text { Process-oriented, lumped, continuous Stream flow } \\
\text { simulation model }\end{array}$ \\
\hline $\begin{array}{l}\text { Great Lakes Environmental Research } \\
\text { Laboratory (GLERL) Model }\end{array}$ & Croley $(1982,1983)$ & $\begin{array}{l}\text { Physically based, semi distributed continuous } \\
\text { simulation model }\end{array}$ \\
\hline $\begin{array}{l}\text { Chemicals, Runoff, and Erosion from } \\
\text { Agricultural Management Systems } \\
\text { (CREAMS) }\end{array}$ & USDA (1980) & $\begin{array}{l}\text { Process-oriented, lumped parameter, agricultural } \\
\text { runoff and water quality model }\end{array}$ \\
\hline $\begin{array}{l}\text { Areal Non-point Source Watershed } \\
\text { Environment Response Simulation } \\
\text { (ANSWERS) }\end{array}$ & $\begin{array}{l}\text { Beasley et al. (1977) and Bouraoui et al. } \\
\text { (2002) }\end{array}$ & $\begin{array}{l}\text { Event-based or continuous, lumped parameter runoff } \\
\text { and sediment yield simulation model }\end{array}$ \\
\hline $\begin{array}{l}\text { Erosion Productivity Impact Calculator (EPIC) } \\
\text { Model }\end{array}$ & $\begin{array}{l}\text { Williams et al. (1984) and Williams } \\
(1995 \mathrm{a}, \mathrm{b})\end{array}$ & $\begin{array}{l}\text { Process-oriented, lumped parameter, continuous } \\
\text { water quantity and quality simulation model }\end{array}$ \\
\hline Technical Report-20 (TR-20) Model & Soil Conservation Service (1965) & $\begin{array}{l}\text { Lumped parameter, event-based runoff simulation } \\
\text { model }\end{array}$ \\
\hline $\begin{array}{l}\text { Agricultural Non-Point Source Model } \\
\text { (AGNPS) }\end{array}$ & Young et al. $(1989,1995)$ & $\begin{array}{l}\text { Distributed parameter, event-based, water quantity } \\
\text { and quality simulation model }\end{array}$ \\
\hline $\begin{array}{l}\text { Groundwater Loading Effects of Agricultural } \\
\text { Management Systems (GLEAMS) }\end{array}$ & $\begin{array}{l}\text { Knisel et al. (1993) and Knisel and } \\
\text { Williams (1995) }\end{array}$ & $\begin{array}{l}\text { Process-oriented, lumped parameter, event-based } \\
\text { water quantity and quality simulation model }\end{array}$ \\
\hline $\begin{array}{l}\text { Generalized River Modeling Package-Systeme } \\
\text { Hydroloque Europeen (MIKE-SHE) }\end{array}$ & Refsgaard and Storm (1995) & $\begin{array}{l}\text { Physically based, distributed, continuous hydrologic } \\
\text { and hydraulic simulation model }\end{array}$ \\
\hline Large Scale Catchment Model (LASCAM) & Sivapalan et al. (1996a, b, c) & $\begin{array}{l}\text { Conceptual, semi distributed, large scale, continuous, } \\
\text { runoff and water quality simulation model }\end{array}$ \\
\hline Hydrologic Model System (HMS) & $\begin{array}{l}\text { Yu and Schwartz (1998) and Yu et al. } \\
\text { (1999) }\end{array}$ & $\begin{array}{l}\text { Physically based, distributed parameter, continuous } \\
\text { hydrologic simulation system }\end{array}$ \\
\hline
\end{tabular}

on runoff, sediment and agricultural chemical yields in large and small watershed (Shrivastava et al. 2004). Application of SWAT model in runoff and sediment yield modeling (Srinivasan et al. 1993, 1998, 2010; Srinivasan and Arnold 1994; Cho et al. 1995; Rosenthal et al. 1995; Bingner et al. 1997; Peterson and Hamlett 1998; Arnold et al. 1999; Shrivastava et al. 2004; Chaplot 2005; Setegn et al. 2008; Betrie et al. 2011; Murty et al. 2013; Suryavanshi 2013) has drawn significant attention over the past two decades due to its simplicity to address wide range of watershed problems at desired spatial and temporal scales. Many researchers have tested the capability of SWAT model under data scare conditions. Ndomba et al. (2008) intended to validate the Soil and Water Assessment Tool (SWAT) model in data scarce environment. Their results indicated the satisfactory performance of swat model with or without the use of observed flows data. The major advantage of the model is that, unlike other conventional conceptual simulation models, it does not require much calibration (Gosain et al. 2005). The SWAT model was originally developed to operate in large-scale ungauged basins with little or no calibration efforts (Arnold et al. 1998). It attempts to incorporate spatially distributed and physically distributed watershed inputs to simulate a set of comprehensive processes, such as hydrology (both surface and subsurface up to the shallow aquifer), sedimentation, crop/vegetative growth, pesticides, bacteria, and comprehensive nutrient cycling in soils, streams, and crop uptake. Most SWAT parameters can be estimated automatically using the GIS interface and meteorological information combined with internal model databases (Srinivasan et al. 1998; Zhang et al. 2008).

Semrakalwana, a small rural village in Allahabad, India has experienced insufficient water supply at the end of the dry seasons. Current village activities that require water included domestic farming system based on surface and 

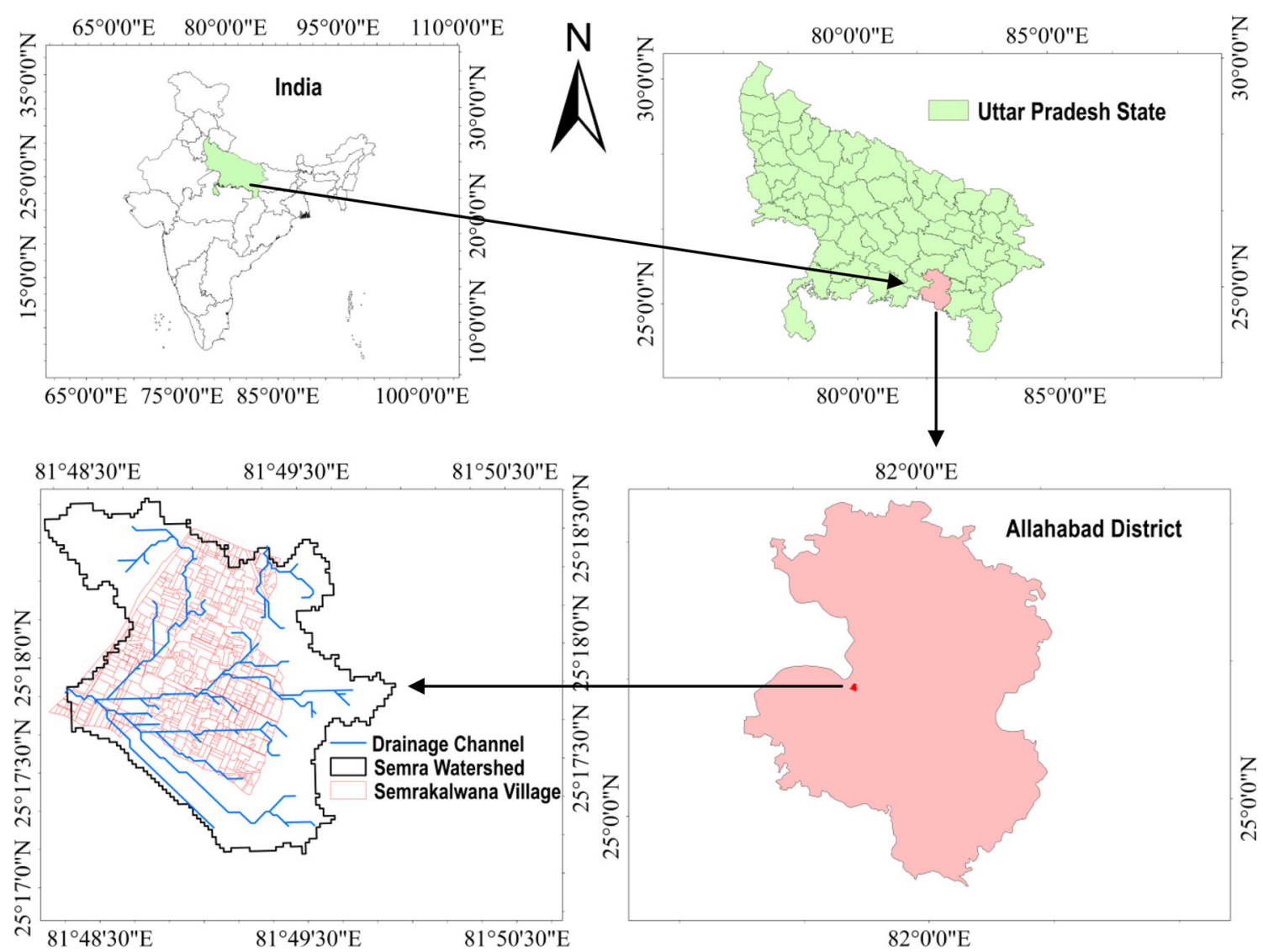

Fig. 1 Location map of study area

ground water. These farming system include Crops, Dairy, Boundary Plantations, goatry, Poultry, Horticulture, Vermicompost, Agro forestry, Piggery activities (Denis 2013).

In India, topographical conditions, soil conditions, rainfall pattern and cultivation practices are different from those in the other parts of the world (Pandey et al. 2008). Therefore, it is required to evaluate the physical based models such as SWAT for a small agricultural dominant watershed. Hence, the present study was carried out with the explicit objective of evaluating SWAT model (in an unguaged catchment) and analysing the water balance components of Semra watershed as well as Semrakalwana village.

\section{Materials and methods}

\section{Description of the study area}

The Semrakalwana village $\left(=4.31 \mathrm{~km}^{2}\right)$, located in Tons river basin is considered as a study area (latitude $25^{\circ} 16^{\prime} 31 \mathrm{~N}$ and longitude $82^{\circ} 4^{\prime} 55 \mathrm{E}$ ) for this present study (Fig. 1). The study area is dominated by loamy soil. The major crops grown in the study area are wheat followed by pulses and potato. Orchards consisting of citrus plants are also grown in the study area. The study area is a part of humid subtropical climate and has an annual mean temperature of $26^{\circ} \mathrm{C}$ with a minimum temperature of $2{ }^{\circ} \mathrm{C}$ in winters and a maximum of $48{ }^{\circ} \mathrm{C}$ in summers. The hot and dry summers begins from the month of March and carries on till June with May being the hottest months while winters falls between the months of November till end of February.

\section{Data acquisition}

\section{Meteorological data}

Historical daily rainfall and minimum and maximum data of eight years (2006-2013) were collected from IMD, Pune. Other meteorological data such as minimum and maximum temperature, solar radiation, relative humidity and PET were collected from Department of Forestry and Environment, Sam Higginbottom Institute of Agriculture, Technology and Sciences, Allahabad.

Rainfall The study area has an average annual rainfall of $1066.8 \mathrm{~mm}$ from the last 8 years data (2006-2013, 

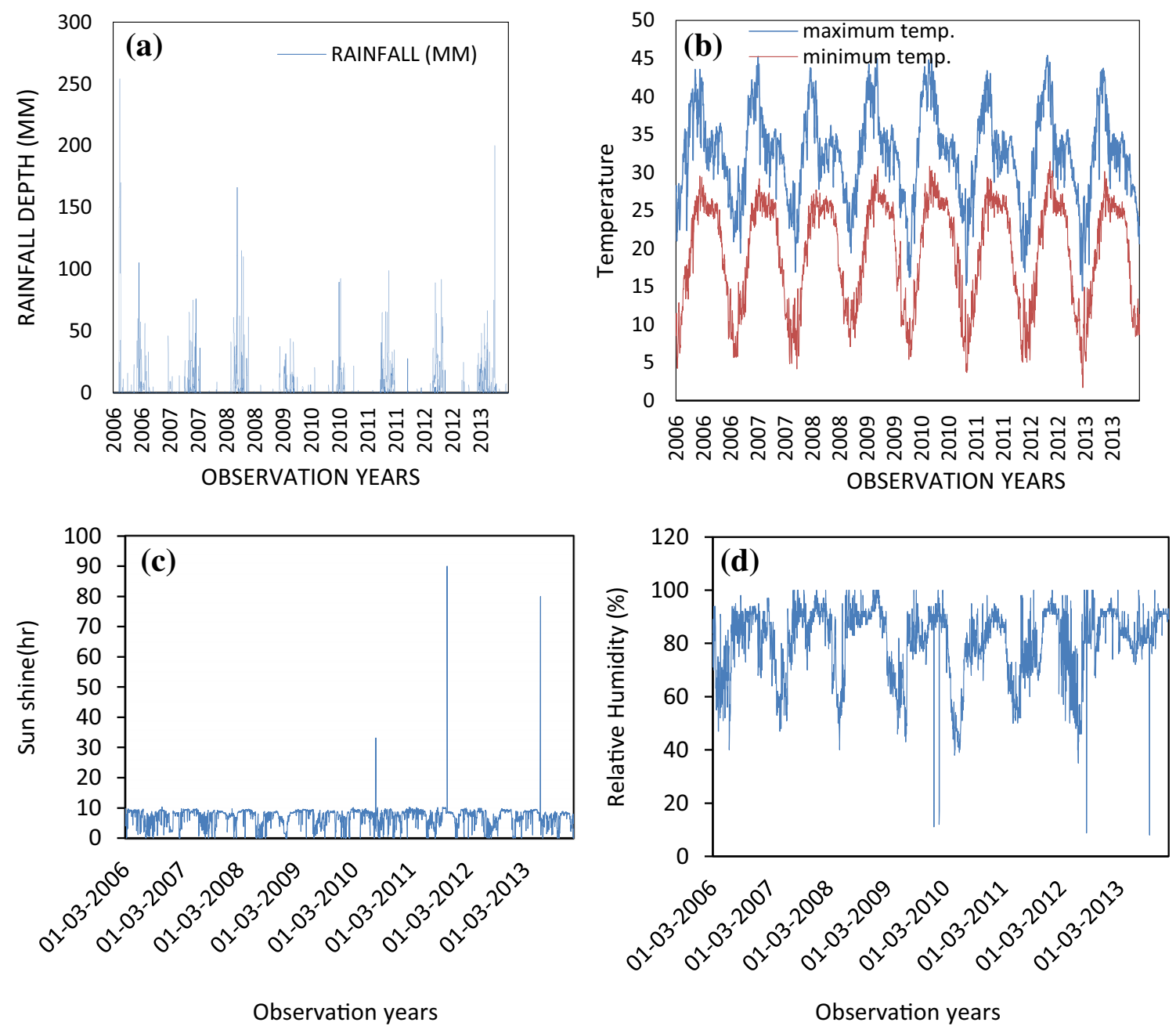

Fig. 2 Daily values of rainfall (a); max and min temperature (b); solar radiation (c) and relative humidity (d) of Allahabad for 2006-2013

recorded by meteorological department Pune). Rainfall is fairly distributed over the area (Fig. 2a).

Temperature The basin experiences a moderate climate with a maximum temperature of $45^{\circ} \mathrm{C}$ and minimum temperature of $29{ }^{\circ} \mathrm{C}$. The maximum temperature was observed during summer season starting from March and ends in the last week of May. Minimum temperature was recorded in January. Monthly variation of minimum and maximum temperature from 2006 to 2013 is shown in Fig. 2b.

Solar radiation The daily (2006-2013) variation of solar radiation of the study area is shown in Fig. 2c.

Relative humidity The daily (2006-2013) relative humidity of the study area remains high with values ranging from 15 to $95 \%$. The pictorial representation of yearly relative humidity is shown in Fig. $2 \mathrm{~d}$.

\section{Satellite data}

The cloud free digital data of the LANDSAT imaginary with $30 \mathrm{~m}$ spatial resolution was used to generate the land use/cover map of the study area (Fig. 3). Most common land use classification method, the supervised classification, was used in this study. The classification was carried out by the Ground Control Points (GCPs). These GCPs were collected with the help of hand held GPS during field visit of the study area during August-December 2014. Each pixel in the image dataset was then categorised into the land use class it most closely resembles. The classified land use/cover classes were found to be agricultural land, rural residential area, waste/barren land and water body.

Advanced Space-borne Thermal Emission and Reflection Radiometer (ASTER) data was used for generation of the digital elevation model (DEM) of the study area (Fig. 4). ASTER elevation data which is available on 
Fig. 3 Land use map of study area

Fig. 4 Digital elevation model of the study area
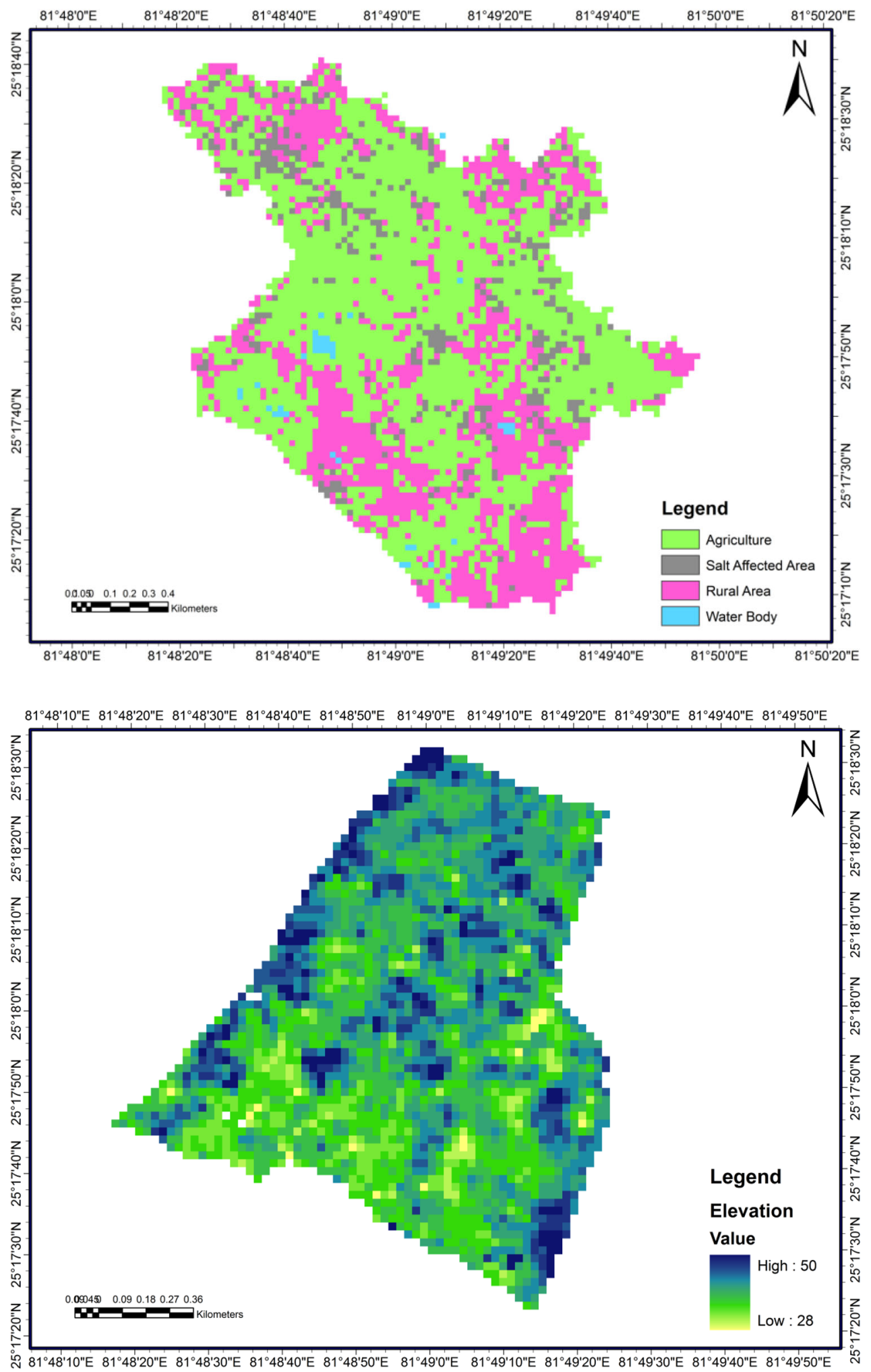

public domain (http://gdem.ersdac.jspacesystems.or.jp) under joint operation of NASA and Japan's Ministry of Economy, Trade and Industry (METI), provides high-resolution images in 15 different bands of the electromagnetic spectrum, ranging from visible to thermal infrared light with resolution of $30 \mathrm{~m}$. The study area comprises loamy and clayey soil association (Fig. 5). Area occupied by each land use, soil and slope classes is presented in Table 2. 
Fig. 5 Soil map of study area

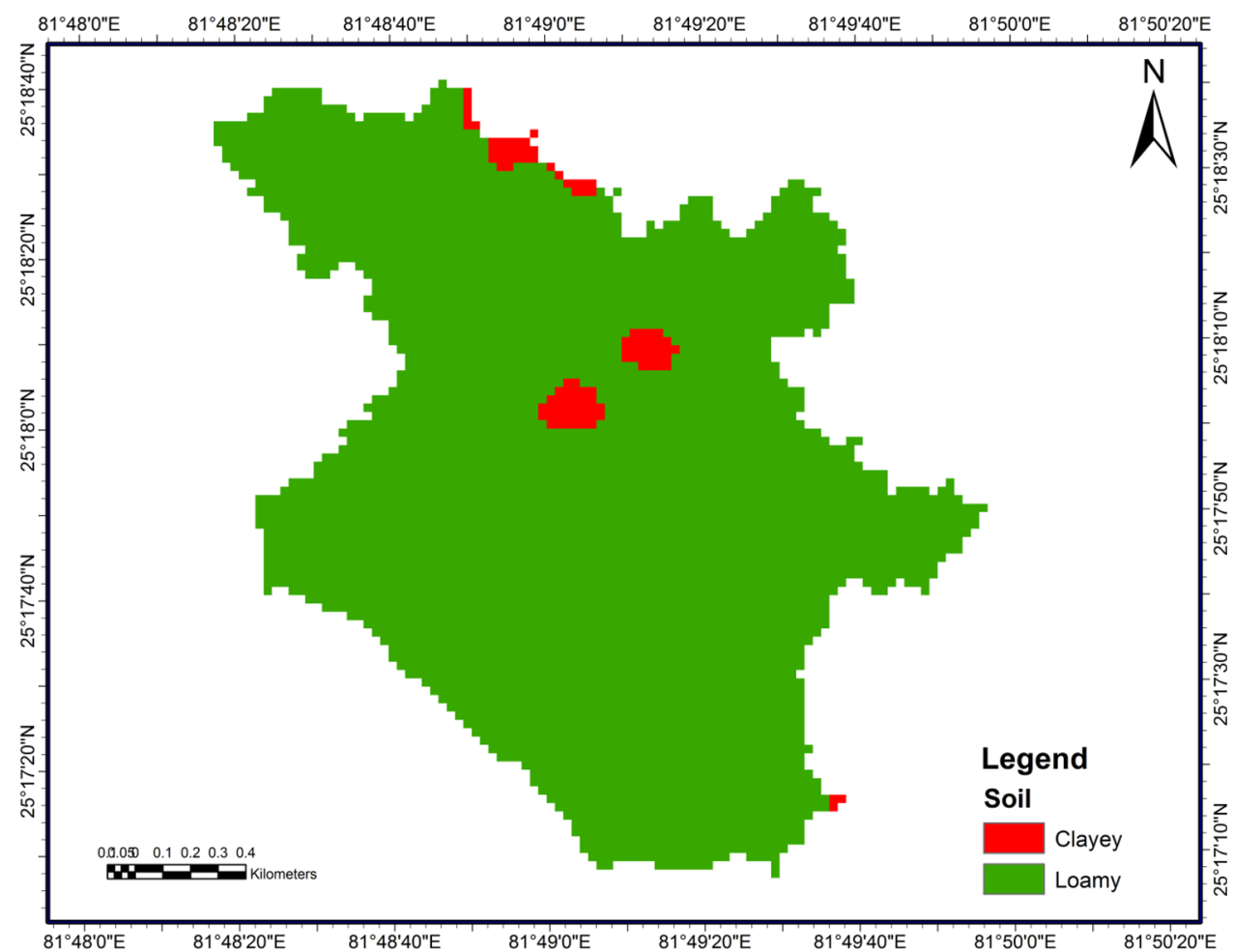

Table 2 Area occupied by each land use, soil and slope classes

\begin{tabular}{lrr}
\hline & Area [ha] & \% of watershed area \\
\hline Land use & & \\
Barren land & 35.73 & 8.29 \\
Rural area & 139.32 & 32.32 \\
Water bodies & 3.78 & 0.88 \\
Agriculture & 252.18 & 58.51 \\
Soil & & \\
Clayey & 9.00 & 2.09 \\
Loamy & 422.01 & 97.91 \\
Slope & & \\
0-3 Degree & 206.73 & 47.96 \\
3-5 Degree & 125.55 & 29.13 \\
5-7 Degree & 62.55 & 14.51 \\
7-10 Degree & 27.09 & 6.29 \\
10 and above degree & 9.09 & 2.11 \\
\hline
\end{tabular}

\section{Brief description of SWAT model}

The SWAT is a continuous time model that operates on a daily/sub-daily time step. It is a physically based model and can operate on large basins for long period of time (Arnold et al. 1998). The SWAT as described by Bian et al. (1996) is a semi-empirical and semi-physically based model. It adopts existing mathematical equations approximating the physical behaviour of the hydrologic system. It is also an advanced lumped or semi-distributed model dividing the catchment into discrete area units for analysis which makes it suitable for integration with a GIS. The Basin is subdivided into sub-basins that are spatially related to one another. This configuration preserves the natural channels and flow paths of the basin. Further, the sub basins are divided into hydrological response units (HRU's). HRUs are discrete areas of similar slope, soil and land use through which water is expected to flow in a more or less homogenous fashion. It lumps the results at the outflow of each unique area. Final results are then summarized for the whole basin at the final outlet. Each of these is analyzed separately to improve the accuracy of the model, but results are lumped per sub basin and averaged for the entire catchment in the final report.

No matter what physical problem is studied using SWAT, water balance is the driving force behind everything that happens in the watershed (Neitsch et al. 2005). Water Balancing simply means; finding out how much water comes into the system and then finding out where that water goes. In terms of water balance storages for each HRU in the watershed, four layered storage possibilities exist. Snow is the first, then a soil profile of up to $2 \mathrm{~m}$, followed by a shallow aquifer underneath it comprising the next $18 \mathrm{~m}$ up to $20 \mathrm{~m}$, and a deep aquifer sitting below $20 \mathrm{~m}$ underground is the final storage space from which water is ultimately completely lost to the SWAT system. Water balance equation used by the SWAT model is given below: 
$\mathrm{SW}_{t}=\mathrm{SW}+\sum_{t-1}^{t}(R-Q-\mathrm{ET}-P-\mathrm{QR})$

where $\mathrm{SW}_{t}$ is the final soil water content $(\mathrm{mm}), \mathrm{SW}$ is the initial soil water content (mm), $t$ is the time (days), $R$ is the amount of precipitation ( $\mathrm{mm}), Q$ is the amount of surface runoff $(\mathrm{mm})$, ET is the amount of evapotranspiration $(\mathrm{mm})$, $P$ is percolation $(\mathrm{mm})$ and $\mathrm{QR}$ is the amount of return flow (mm).

\section{SWAT model setup for the study area}

The SWAT model setup was carried out with Arc GIS interface (Arc SWAT 2009.93.7a). The interface helped in watershed parameterization and model input. The input parameters of the model were extracted from the satellite imageries, DEM analysis, soil maps and field observations. The stream network was generated by the use of a threshold area that defines the origin of a stream. The delineation scheme with moderate subdivision level gives the best modeling efficiency (Gong et al. 2010). In this study, threshold value is considered as 0.5 ha. Hydrological response units (HRUs) were created using unique land use/cover, soil and slope layers. A total number of two sub basins and 50 HRUs were created in the study area.

\section{Criteria for model evaluation}

For scientifically sound model evaluation, a combination of different efficiency criteria is recommended (Krause et al. 2005). In this study, well-known statistical criterion such as Coefficient of determination $\left(R^{2}\right)$, Nash-Sutcliffe coefficient $\left(E_{\mathrm{NS}}\right)$, Index of agreement $(d)$, Modified forms of Nash-Sutcliffe coefficient $(E)$ and Index of agreement $(d 1)$, Percent bias (PBIAS) and RMSE-observations Standard deviation Ratio (RSR) were used to evaluate model performance where, $Y_{i}^{\text {obs }}$ is the $i$ th observed data, $Y_{\text {mean }}^{\text {obs }}$ is mean of observed data, $Y_{i}^{\text {sim }}$ is the $i$ th simulated value, $Y_{\text {mean }}^{\text {sim }}$ is the mean of model simulated value, and $N$ is the total number of events.

The coefficient of determination $\left(R^{2}\right)$ Willmot (1981) and Legates and McCabe (1999)

$R^{2}=\left(\frac{\sum_{i=0}^{n}\left(Y_{i}^{\mathrm{obs}}-Y_{\mathrm{mean}}^{\mathrm{obs}}\right)\left(Y_{i}^{\mathrm{sim}}-Y_{\text {mean }}^{\mathrm{sim}}\right)}{\sqrt{\sum_{i=1}^{n}\left(Y_{i}^{\mathrm{obs}}-Y_{\text {mean }}^{\mathrm{obs}}\right)^{2} \sqrt{\sum_{i=1}^{n}\left(Y_{i}^{\mathrm{sim}}-Y_{\text {mean }}^{\mathrm{sim}}\right)^{2}}}}\right)^{2}$

Nash-Sutcliffe coefficient $\left(E_{N S}\right)$ Nash and Sutcliffe (1970)

$E_{\mathrm{NS}}=1-\left[\frac{\sum_{i=1}^{n}\left(Y_{i}^{\mathrm{obs}}-Y_{i}^{\mathrm{sim}}\right)^{2}}{\sum_{i=1}^{n}\left(Y_{i}^{\mathrm{obs}}-Y_{\text {mean }}^{\mathrm{obs}}\right)^{2}}\right]$
Index of agreement (d) Willmot (1981)

$d=1-\frac{\sum_{i=1}^{n}\left|Y_{i}^{\mathrm{obs}}-Y_{i}^{\mathrm{sim}}\right|^{2}}{\sum_{i=1}^{n}\left(\left|Y_{i}^{\mathrm{sim}}-Y_{\text {mean }}^{\text {obs }}\right|+\left|Y_{i}^{\text {obs }}-Y_{\text {mean }}^{\mathrm{obs}}\right|\right)^{2}}$

Modified forms of Nash-Sutcliffe coefficient (E) and Index of agreement (d1) Krause et al. (2005)

$E=1-\frac{\sum_{i=1}^{n}\left|Y_{i}^{\text {obs }}-Y_{i}^{\text {sim }}\right|^{j}}{\sum_{i=1}^{n}\left|Y_{i}^{\text {obs }}-Y_{\text {mean }}^{\text {obs }}\right|^{j}} \quad$ with $j \in N$

$d 1=1-\frac{\sum_{i=1}^{n}\left|Y_{i}^{\mathrm{obs}}-Y_{i}^{\mathrm{sim}}\right|^{j}}{\sum_{i=1}^{n}\left(\left|Y_{i}^{\mathrm{sim}}-Y_{\text {mean }}^{\text {obs }}\right|+\left|Y_{i}^{\text {obs }}-Y_{\text {mean }}^{\text {obs }}\right|\right)^{j}}$

with $j \in N$

Percent bias (PBIAS) Gupta et al. (1999)

PBIAS $=\left[\frac{\sum_{i=1}^{n}\left(Y_{i}^{\text {obs }}-Y_{i}^{\text {sim }}\right) \times(100)}{\sum_{i=1}^{n}\left(Y_{i}^{\text {obs }}\right)}\right]$

RMSE-observations Standard deviation Ratio (RSR) Chu and Shirmohammadi (2004), Singh et al. (2004), VazquezAmábile and Engel (2005) and Legates and McCabe (1999)

$\mathrm{RSR}=\frac{\mathrm{RMSE}_{\mathrm{STDEV}}}{\mathrm{obs}}=\frac{\left[\sqrt{\sum_{i=1}^{n}\left(Y_{i}^{\mathrm{obs}}-Y_{i}^{\mathrm{sim}}\right)^{2}}\right]}{\left[\sqrt{\sum_{i=1}^{n}\left(Y_{i}^{\mathrm{obs}}-Y_{i}^{\mathrm{sim}}\right)^{2}}\right]}$

\section{Sensitivity analysis of SWAT model parameters}

Sensitivity analysis was carried out to examine the relative changes in the flow with respect to change in selected model input variables. In this study, a LH-OAT sensitivity analysis, which is incorporated in SWAT, is used to perform sensitivity analysis. The analysis was carried out based on the objective function of the SSQ for 20 model parameters and 10 intervals of LH sampling. After set-up of the SWAT model and incorporating all the input parameters simulations were carried out and sensitivity analysis was run for the period of 8 years (2006-2013). The parameters selected for the sensitivity analysis and their rank with the mean values after analyzing their sensitivity to flow are exhibited in Table 3 . The parameter producing the highest average percentage change in the objective function value is ranked as most sensitive. The result of the sensitivity analysis indicates that, $\mathrm{CN}$ is the most sensitive parameter to the output followed by soil evaporation compensation factor (ESCO), available water capacity of the soil layer (SOL_AWC), soil depth (SOL_Z) maximum potential leaf area index (BLAI), threshold depth of water in the shallow aquifer for return flow to occur (GWQMN) groundwater revap coefficient (GW_REVAP), maximum canopy storage (CANMX), hydraulic 
Table 3 SWAT parameters with rank according to sensitivity to the simulated output

\begin{tabular}{|c|c|c|c|c|}
\hline Rank & Name & Description & Process & Mean value \\
\hline 1 & $\mathrm{CN}$ & Soil conservation service runoff curve number for AMC II & Runoff & 0.526 \\
\hline 2 & ESCO & Soil evaporation compensation factor & Evaporation & 0.322 \\
\hline 3 & SOL_AWC & Available water capacity of the soil layer & Soil & 0.285 \\
\hline 4 & SOL_Z & Soil depth & Soil & 0.102 \\
\hline 5 & BLAI & Maximum potential leaf area index & Crop & $0.634 \times 10^{-1}$ \\
\hline 6 & GWQMN & Threshold depth of water in the shallow aquifer required for return flow to occur & Groundwater & $0.554 \times 10^{-1}$ \\
\hline 7 & GW_REVAP & Groundwater revap coefficient & Groundwater & $0.543 \times 10^{-1}$ \\
\hline 8 & CANMX & Maximum canopy storage & Soil & $0.289 \times 10^{-1}$ \\
\hline 9 & CH_K2 & Hydraulic conductivity in main channel & Channel & $0.201 \times 10^{-1}$ \\
\hline 10 & REVAPMN & Threshold depth of water in shallow aquifer for revap to occur & Groundwater & $0.816 \times 10^{-2}$ \\
\hline 11 & SOL_K & Soil conductivity & Soil & $0.625 \times 10^{-2}$ \\
\hline 12 & SURLAG & Surface runoff lag coefficient & Runoff & $0.566 \times 10^{-2}$ \\
\hline 13 & ALPHA_BF & Baseflow alpha factor & Groundwater & $0.322 \times 10^{-2}$ \\
\hline 14 & SOIL_ALB & Soil albedo & Evaporation & $0.208 \times 10^{-2}$ \\
\hline 15 & EPCO & Plant evaporation compensation factor & Evaporation & $0.158 \times 10^{-2}$ \\
\hline 16 & CH_N2 & Manning coefficient for main channel & Channel & $0.156 \times 10^{-2}$ \\
\hline 17 & GW_DELAY & Groundwater delay & Channel & $0.144 \times 10^{-2}$ \\
\hline 18 & BIOMIX & Biological mixing efficiency & Management & $0.292 \times 10^{-3}$ \\
\hline 19 & SLOPE & Average slope steepness & Geomorphology & $0.287 \times 10^{-3}$ \\
\hline 20 & SLSUBBSN & Average slope length & Geomorphology & $0.154 \times 10^{-3}$ \\
\hline
\end{tabular}

conductivity in main channel (CH_K2) and threshold depth of water in shallow aquifer for revap to occur (REVAPMN), respectively. The least sensitive parameters observed were average slope length (SLSUBBSN), average slope steepness (SLOPE) and biological mixing efficiency (BIOMIX), respectively. Sensitivity analysis indicated the overall importance of all parameters in determining the runoff of the study area. All the parameters generally govern the surface and subsurface hydrological processes and stream routing. These results illustrates how parameter sensitivity is site specific and depends on land use, topography and soil types compared to other studies.

\section{Evaluation of SWAT model}

The study area (Semra watershed) is a small ungauged watershed. For the study area, stream flow data was not available. Due to this limitation proper model calibration was not performed in this study. The study has to rely on the next foremost component of hydrological cycle, i.e. Evapotranspiration. An attempt was made to evaluate the performance of the SWAT model with the help of observed ETP data obtained from SHIATS weather station for a period 2008-2013. The main focus of this manuscript is evaluating SWAT model in an unguaged catchment and analysing the water balance components. The major advantage of the SWAT model is that unlike the other conventional conceptual simulation models, it does not

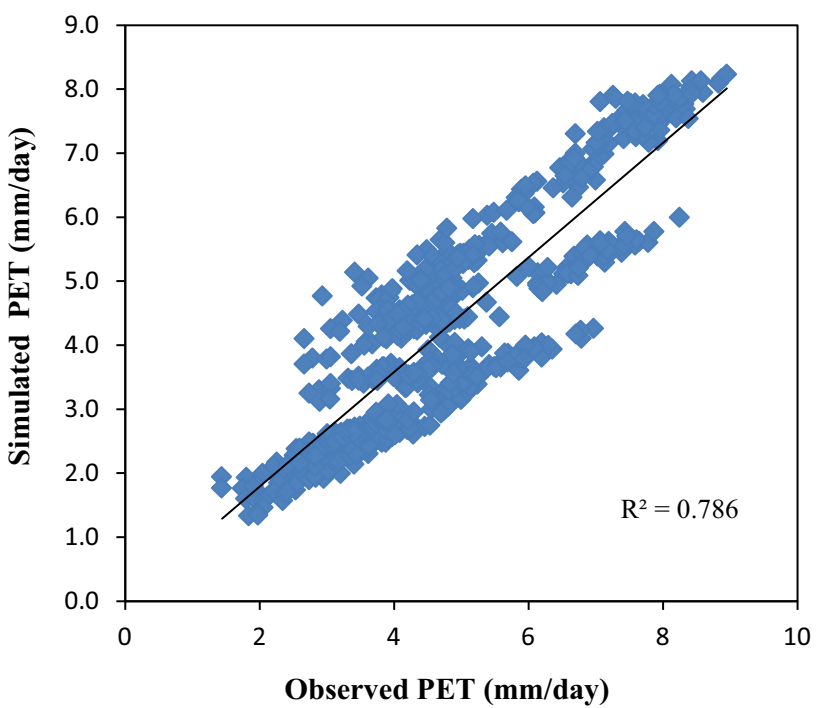

Fig. 6 Comparison between the daily observed and predicted PET from 2008 to 2013 for model validation

require much calibration, and therefore, can be used on ungauged watersheds (in fact, the usual situation) (Gosain et al. 2005, 2006, 2011; Margaret et al. 2015).

The observed and simulated daily ETP for the validation period along with 1:1 line is shown in Fig. 6. It is observed from the figure that the simulated ETP values are distributed uniformly about the 1:1 line. A high value of coefficient of determination $\left(R^{2}=0.78\right)$ indicates a close 
Table 4 Statistical analysis of observed and simulated ETP for the years 2008-2013

\begin{tabular}{lll}
\hline Statistical parameters & Range of variability & Values obtained \\
\hline Coefficient of determination & 0 to 1 & 0.78 \\
Nash-Sutcliffe efficiency & $-\infty$ to 1 & 0.77 \\
Index of agreement & 0 to 1 & 0.83 \\
Modified form of Nash-Sutcliffe coefficient & $-\infty$ to & 0.71 \\
Modified form of Index of agreement & 0 to 1 & 0.73 \\
Percent bias & $-\infty$ to $+\infty$ optimal value is 0 & 3.19 \\
RMSE-observations Standard deviation Ratio & $-\infty$ to $+\infty$ optimal value is 0 & 3.97 \\
\hline
\end{tabular}

relationship between the observed and simulated ETP. Further, the efficiency of the model for simulating ETP was tested by statistical analysis and the results are presented in Table 4. A high value of Nash-Sutcliffe model efficiency of 0.77 indicates that there is a good agreement between the observed and simulated ETP during evaluation period. The range of index of agreement, modified forms of NashSutcliffe coefficient $(E)$ and modified forms of index of agreement ( $d 1)$ are similar to that of $R^{2}$ and lies between 0 (no correlation) and 1 (perfect fit) and found to be 0.83 , 0.71 and 0.73 , respectively. The optimal value of PBIAS is 0.0 , with low-magnitude values indicating accurate model simulation. Positive values indicate model underestimation bias, and negative values indicate model overestimation bias (Gupta et al. 1999). The value of PBIAS was found to be 3.19. RSR varies from the optimal value of 0 to a large positive value. The lower is the RSR, the lower RMSE, and the better the model simulation performance (Krause et al. 2005). The RSR value was found to be 3.97 which can be termed as "good rating". Thus, the results indicate that the overall prediction of ETP by the SWAT model during the evaluation period was satisfactory, and therefore, can be employed in a small agricultural dominated unguaged watershed.

\section{Water balancing of Semrakalwana village}

A water balancing analysis was performed in the Semrakalwana village which is a part of Semra watershed. Water balancing analysis was performed on hydrologic response unit (HRU) basis. This is the smallest spatial unit of the model, and this approach lumps all similar land uses, soils, and slopes within a sub-basin based upon user-defined thresholds. Figure 7 depicts the spatial distribution of various water balance component on HRU basis. For the Semrakalwana village, average annual rainfall was found to be 1064-1066 $\mathrm{mm}$. The average annual surface runoff varied from 379 to $386 \mathrm{~mm}$ while the evapotranspiration of the village was in the range of 359-364 $\mathrm{mm}$. The average annual percolation and return flow was found to be $265-272 \mathrm{~mm}$ and 147-255 mm, respectively. The initial soil water content of the village was found in the range of 328-335 $\mathrm{mm}$ while the final soil water content was 356-362 mm.

\section{Water balance analysis of Semra watershed}

An analysis was also performed out to evaluate the seasonal and yearly water balance of the Semra watershed for the period of 2008-2013 (6 years). The water balancing analysis was classified into three seasons, i.e. Kharif season (AugustOctober), Rabi season (November-April) and Zaid season (May-July). The water balance of Semra watershed consisting rainfall, evapotranspiration, surface runoff and water yield components are exhibited in Table 5.

\section{Kharif season}

It is observed from Table 5, that about 50\% (530.14 mm) of annual rainfall $(1066.8 \mathrm{~mm})$ occurs during Kharif season. Out of total yearly runoff of $421.88 \mathrm{~mm}$ about $45 \%$ of runoff occurs in Kharif season. The water yield (water that leaves the sub basin and contributes to stream flow that is Runoff + groundwater flow in shallow aquifer-transmission losses) in Kharif season was almost $46 \%$ of the annual water yield $(705.65 \mathrm{~mm})$. The study area falls under the Tons river basin. Tons basin is a rain-fed river so the hydrology of the study area is greatly influenced by rainfall. The Tons river swells up and floods occur during rainy season and dries up in the summer. Therefore, if the water is not stored in Kharif season, famine like conditions is created during the remaining part of the year. ET contribution in the Kharif season was found to be $46.51 \%$ (151.69) of yearly ET. ET has a large impact on water and other natural resources and distribution and abundance of these resources are governed by the volume and seasonality of available moisture (Neilson et al. 1992).

\section{Rabi season}

This is lean season with average rainfall of only $197.1 \mathrm{~mm}$ (Table 5). The runoff contribution in Rabi season is about $18 \%$ of the yearly runoff. Being a rain-fed watershed, the 


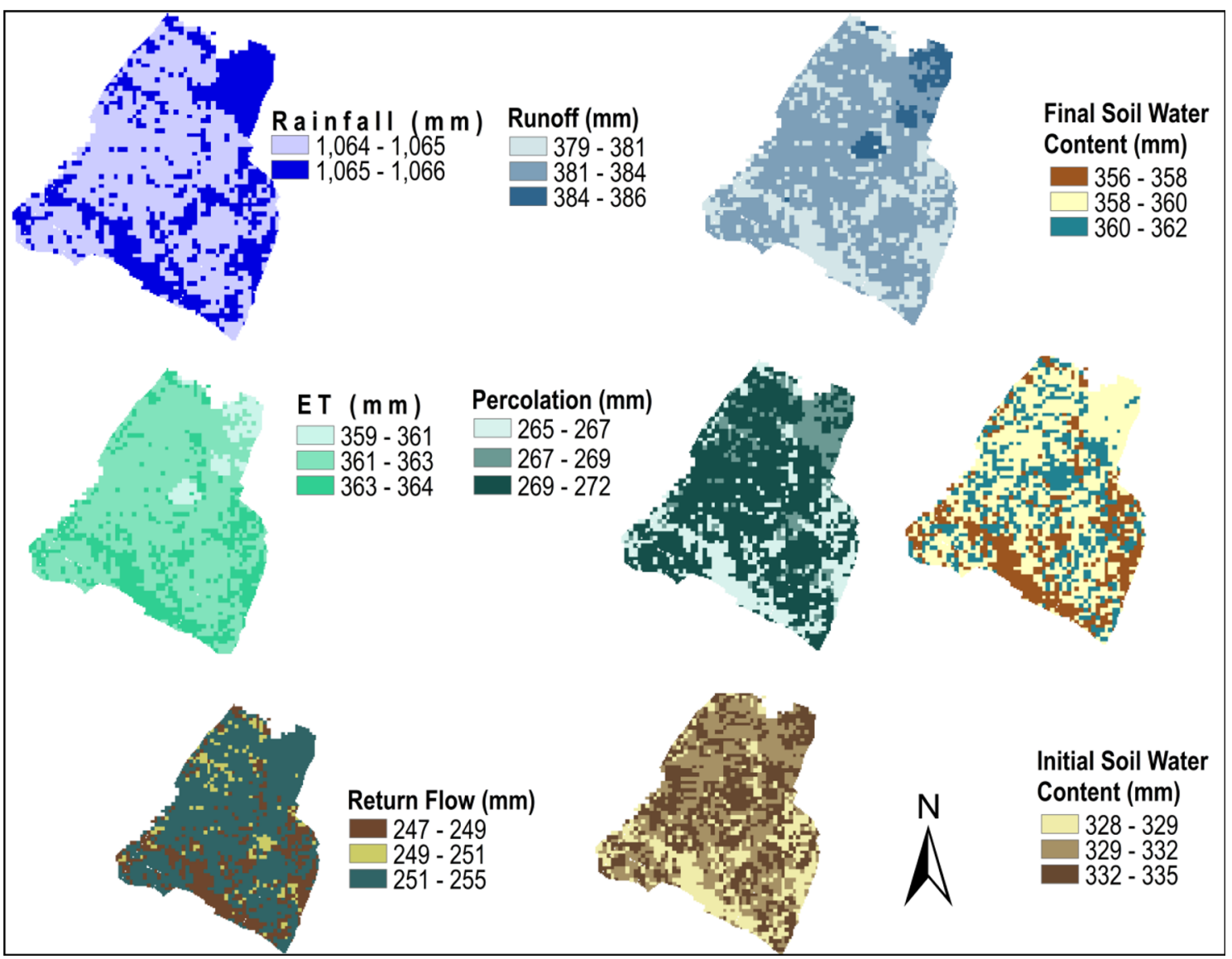

Fig. 7 Spatial distribution of various water balance component of Semrakalawan village

Table 5 Average seasonal and annual water balance of Semra watershed

\begin{tabular}{lcccc}
\hline Seasons & $\begin{array}{l}\text { Rainfall } \\
(\mathrm{mm})\end{array}$ & $\begin{array}{l}\text { Runoff } \\
(\mathrm{mm})\end{array}$ & $\begin{array}{l}\text { Water yield } \\
(\mathrm{mm})\end{array}$ & $\begin{array}{l}\text { ET } \\
(\mathrm{mm})\end{array}$ \\
\hline Rabi season & 88.35 & 31.87 & 54.49 & 25.28 \\
$\begin{array}{l}\text { Kharif } \\
\quad \text { season }\end{array}$ & 65.7 & 25.62 & 49.57 & 26.32 \\
Zaid season & 113.87 & 51.49 & 77.03 & 31.99 \\
Annual & 1066.8 & 421.88 & 705.65 & 326.1 \\
\hline
\end{tabular}

Rabi season (winter crop season) is adversely affected due to less availability of water for crops. It has to be noted that the economic conditions of the people restricts the cultivators to put up tube wells, shallow wells or tanks with their own resources. ET contribution in the Rabi season was found to be $24 \%$ of the yearly ET. The water yield from this season is $148.72 \mathrm{~mm}$ which is $21 \%$ of the annual water yield contribution. Water yield was found to be lowest in this season (compare to Kharif and Zaid) may be because the unsaturated condition of the soil in the study area and the reduction in the quantity of the rainfall followed by the reduction in the surface runoff contribution to the stream flow during this season.

\section{Zaid season}

About 32\% (341.63 mm) of the yearly rainfall occurred in Zaid season (Table 5). The percentage of runoff occurred in the study area in Zaid season is about 37\% (154.47 $\mathrm{mm}$ ) of the yearly runoff $(421.88 \mathrm{~mm})$. On the other hand the ET contribution in this season was found to be about $29 \%$ (95.99 $\mathrm{mm}$ ) of yearly ET. Water yield was found to be $231.1 \mathrm{~mm}$ which is $33 \%$ of the annual water yield.

\section{Yearly water balance}

It was observed that, out of $1066.8 \mathrm{~mm}$ annual average rainfall, $421.88 \mathrm{~mm}$ flows out as surface runoff from the study area (Table 5). The annual average water yield was found to be $705.65 \mathrm{~mm}$. While the average annual ET of the study area was $326.1 \mathrm{~mm}$. The study area is agricultural dominated watershed; however, the economic condition of a large population depends on agriculture, remains underprivileged due to agro-climatic condition and poor management of water resources. Conservation structures such as check dams, farm ponds, tanks, stop dams, rock fill dams, percolation tank, vegetative barrier can be 
constructed in study area to reduce monsoon runoff and conserve it for basin requirements in lean period. Appropriate best management practices like strip cropping, grassed waterways and vegetative filter strips can also be implemented for better water management.

\section{Summary and conclusions}

SWAT model was appraised to be a fair model for waterbalance study in the agricultural dominated sub basins. Due to unavailability of the observed runoff data, the performance of the model was evaluated using observed PET. The results of SWAT model revealed that the SWAT model does not require much calibration and can be used in predicting the water balancing components of the study area. The SWAT model was applied to analyze seasonal and annual water budget for Semrakalwana village and Semra watershed. Water balancing analysis of Semrakalwana village was performed on HRU basis. The average annual rainfall and runoff was found to be nearly 1065 and $383 \mathrm{~mm}$, respectively. The evapotranspiration of the village was found to be approximately $362 \mathrm{~mm}$. The average annual percolation and return flow was found to be approximately 270 and $147-255 \mathrm{~mm}$, respectively. The initial soil water content of the village was found in the range of $328-335 \mathrm{~mm}$ while the final soil water content was 356-362 mm. The water balancing analysis was also performed on seasonal (Kharif, Rabi and Zaid seasons) as well as on yearly basis. The seasonal hydrological assessment exhibited that about $50 \%$ of annual rainfall (1066.8 mm) occurs during Kharif season. In the Rabi season which is lean season, rainfall was found to be $197.1 \mathrm{~mm}$ and during the season of Zaid the rainfall was about $341 \mathrm{~mm}$. The water yield (water that leaves the sub basin and contributes to stream flow) in Kharif season was almost $46 \%$ of the annual water yield. In the Rabi season it was found to be lowest with $148.72 \mathrm{~mm}$ while in the season of Zaid it was found to be $231.1 \mathrm{~mm}$. ET contribution in the Kharif season was found to be $46.51 \%$ (151.69) of yearly ET. In the Rabi and Zaid seasons ET was found to be 78.96 and $95.99 \mathrm{~mm}$, respectively. The yearly water balance revealed that out of $1066.8 \mathrm{~mm}$ annual average rainfall, $421.88 \mathrm{~mm}$ flows out as surface runoff. The annual average water yield was $705.65 \mathrm{~mm}$ and the average annual ET of the study area was found to be $326.1 \mathrm{~mm}$.

The geological features of the study area and economic condition of the people, circumscribes the use of tube wells, shallow wells or tanks with their own resources. Moreover, the economic condition of a large population depends on agriculture and allied activities, remains underprivileged due to uncertain agro-climatic condition and poor management of water resources. As the study area fall under a rain-fed river basin (Tons river basin) with no contribution from snowmelt, the winter and summer season are highly affected by less water availability for crops and municipal use. Appropriate best management practices like strip cropping, grassed waterways and vegetative filter strips can also be employed for better water management in the basin.

Acknowledgements The authors duly acknowledge the grant received by Uttar Pradesh Council of Agricultural Research, Lucknow, Uttar Pradesh for funding this research under the project "Farming System Based Water Budgeting for Samrakalwana Village at Allahabad". The cooperation received by the farmers of Samrakalwana Village in collection of data is also acknowledged.

Open Access This article is distributed under the terms of the Creative Commons Attribution 4.0 International License (http:// creativecommons.org/licenses/by/4.0/), which permits unrestricted use, distribution, and reproduction in any medium, provided you give appropriate credit to the original author(s) and the source, provide a link to the Creative Commons license, and indicate if changes were made.

\section{References}

Abbott MB, Bathurst JC, Cunge JA, O'Connell PE, Rasmussen J (1986) An introduction to the European Hydrological SystemSysteme Hydrologique Europeen, "SHE", History and philosophy of a physically-based distributed modeling system. J Hydrol 87:45-59

Andrews WH, Riley JP, Masteller MB (1978) Mathematical modeling of a sociological and hydrological system. ISSR Research Monograph. Utah Water Research Laboratory, Utah State University, Logan, UT

Arnold JG, Srinivasan R, Muttiah RS, Williams JR (1998) Large area hydrologic modeling and assessment: part I, model development. J Am Water Resour Assoc 34(1):73-89

Arnold JG, Srinivasan R, Ramanarayanan TS, Diluzio M (1999) Water resources of the Texas gulf basin. Water Sci Technol 39(3):121-133

Bathurst JC, O'Connell PE (1992) Future of distributed modelling: the Systeme Hydrologique Europeen. Hydrol Process 6:265-277

Bian L, Sun H, Blodgett C, Egbert S, Li WP, Ran LM, Koussis A (1996). An integrated interface system to couple the SWAT model and Arc/Info, Third International Conference/Workshop on Integrating GIS and Environmental Modeling, Santa Fe: New Mexico

Beasley DB, Monke EJ, Huggins LF (1977) ANSWERS: a model for watershed planning, Purdue Agricultural Experimental Station Paper No. 7038, Purdue University, West Lafayette, IN

Bergstrom S (1976) Development and application of a conceptual runoff model for Scandinavian countries. SMHI Report No. 7, Norrkoping, Sweden

Bergstrom S (1992) The HBV model-its structure and applications. SMHI Report RH, No. 4, Norrkoping, Sweden

Betrie GD, Mohamed YA, Van GA, Srinivasan R (2011) Sediment management modeling in the Blue Nile basin using SWAT model. Hydrol Earth Syst Sci 15:807-818

Beven KJ, Claver A. Morris EM (1987) The Institute of Hydrology Distributed model, Institute of Hydrology. Report No: 98. Accessed on July 2015

Bingner RL, Garbrecht J, Arnold JG, Srinivasan R (1997) Effect of watershed division on simulation of runoff and fine sediment yield. Trans Am Soc Agric Eng 40(5):1329-1335 
Bouraoui F, Braud I, Dillaha TA (2002) ANSWERS: a nonpoint source pollution model for water, sediment and nutrient losses. In: Singh VP, Frevert DK (eds) Mathematical models of small watershed hydrology and applications. Water Resources Publications, Littleton, $\mathrm{CO}$

Chu TW, Shirmohammadi A (2004) Evaluation of the SWAT model's hydrology component in the piedmont physiographic region of Maryland. Trans Am Soc Agric Eng 47(4):1057-1073

Chaplot V (2005) Impact of DEM mesh size and soil map scale on SWAT runoff, sediment, and NO3-N loads predictions. J Hydrol 312:207-222

Cho SM, Jennings GD, Stallings C, Devine HA (1995) GIS-based water quality model calibration in the Delaware River basin. Transactions of American Society of Agricultural Engineering Microfiche No. 952404 ASAE, St. Joseph, Michigan

Croley TE (1982) Great Lake basins runoff modeling. NOAA Technical Memorandum No. EER GLERL-39, National Technical Information Service, Springfield

Croley TE (1983) Lake Ontario basin runoff modeling. NOAA Technical Memorandum No. ERL GLERL-43, Great Lakes Environmental Research Laboratory, Ann Arbor, MI

Denis DM (2013) Long Irrigation Performance Assessment using SEBS and SCOPE - A case study of Tons pump Canal Command in India. Unpublished Postgraduation thesis Faculty of Geo-Information Science and Earth Observation University of Twente

Feldman AD (1981) HEC models for water resources system simulation: theory and experience. Adv Hydrosci 12:297-423

Gupta HV, Sorooshian S, Yapo PO (1999) Status of automatic calibration for hydrologic models: comparison with multilevel expert calibration. J Hydrol Eng 4(2):135-143

Gong Y et al (2010) Effect of watershed subdivision on SWAT modelling with consideration of parameter uncertainty. J Hydrol Eng 15(12):15-22

Gosain AK, Rao S, Arora A (2011) Climate change impact assessment of water resources of India. Curr Sci 101(3):356-371

Gosain AK, Rao S, Basuray D (2006) Climate change impact assessment on hydrology of Indian River basins. Curr Sci 90(3):346-353

Gosain AK, Rao S, Srinivasan R, Reddy NG (2005) Return-flow assessment for irrigation command in the Palleru river basin using SWAT model. Hydrol Process 19:673-682

Grayson RB, Moore ID, McMahon TA (1992) Physically 379 based hydrologic modeling: Is the concept realistic? Water Resour Res 26:2659-2666

HEC (1981) HEC-1 flood hydrograph package: users manual. U.S Army Corps of Engineers, Davis, CA

Huggins LF, Monke EJ (1970) Mathematical simulation of hydrologic events of ungaged watersheds. Water Resources Research Center, Technical Report No. 14, Purdue University, West Lafayette, IN

Huber WC (1995) EPA storm water management model SWMM. In: Singh VP (ed) Computer models of watershed hydrology, chap 22. Water Resources Publications, Littleton, CO

Huber WC, Dickinson RE (1988) Storm water management model user's manual, version 4. Report No. EPA/600/3-88/001a, U.S. Environmental Protection Agency, Athens

Knisel WG, Williams JR (1995) Hydrology components of CREAMS and GLEAMS models. In: Singh VP (ed) Computer models of watershed hydrology, chap 28. Water Resources Publications, Littleton, CO

Knisel WG, Leonard RA, Davis FM, Nicks AD (1993) GLEAMS version 2.10, part III, user's manual. Conservation Research Report, USDA, Washington, DC

Krause P, Boyle DP, Base F (2005) Comparison of different efficiency criteria for hydrological model assessment. Adv Geosci 5:89-97
Legates DR, McCabe GJ (1999) Evaluating the use of goodness-of-fit measures in hydrologic and hydroclimatic model validation. Water Resour Res 35(1):233-241

Margaret MK, Chaubey I, Frankenberger J (2015) Defining Soil and Water Assessment Tool (SWAT) hydrologic response units (HRUs) by field boundaries. Int J Agric Biol Eng 8:1

Metcalf and Eddy, Inc., Univ. of Florida, and Water Resources Engineers, Inc. (1971) Storm water management model, vol 1. Final report, EPA Report No. 11024DOC07/71 (NITS PB203289), EPA, Washington, DC

Murty PS, Pandey A, Suryavanshi S (2013) Application of semidistributed hydrological model for basin level water balance of the Ken basin of Central India. Hydrol Process 28(13):4119-4129

Nash JE, Sutcliffe JV (1970) River flow forecasting through conceptual models part 1-A discussion of principals. J Hydrol 10(3):282-290

Neilson RP, King GA, Koerper G (1992) Toward a rule based biome model. Landsc Ecol 7:27-43. doi:10.1007/BF02573955

Neitsch SL, Arnold JG, Kiniry JR, Williams JR (2005) Soil and Water Assessment Tool, theoretical documentation. Black Land Research and Extension Center, Texas Agricultural Experiment Station Texas

Ndomba P, Mtalo F, Killingtveit A (2008) SWAT model application in a data scarce tropical complex catchment in Tanzania. Physics and Chemistry of the Earth 33:626-632

Pandey A, Chowdary VM, Mal BC, Billib M (2008) Runoff and sediment yield modeling from a small agricultural watershed in India using the WEPP model. J Hydrol 348:305-319

Peterson JR, Hamlett JM (1998) Hydrological calibration of the SWAT model in a watershed containing fragipan soils. J Am Water Resour Assoc 34(3):531-544

Refsgaard JC, Storm B (1995) MIKE SHE. In: Singh VP (ed) Computer models of watershed hydrology. Water Resources Publications, Englewood, USA, pp 809-846

Rosenthal WD, Srinivasan R, Arnold JG (1995) Alternative river management using a linked GIS-hydrology model. Trans ASCE 38(3):783-790

Singh J, Knapp HV, Demissie M (2004). Hydrologic modeling of the Iroquois River watershed using HSPF and SWAT, ISWS CR 2004-08, Champaign, Ill.: Illinois State Water Survey, http:// www.sws.uiuc.edu/pubdoc/CR/ISWSCR2004-08.pdf. Accessed 10 March 2011.

Shrivastava RK, Tripathi MP, Das SN (2004) Hydrological modeling of a small watershed using satellite data and GIS technique. J Indian Soc Remote Sens 32(2):145-157. doi:10.1007/ BF03030871

Setegn SG, Srinivasan R, Dargahi B (2008) Hydrological modeling in lake Tana Basin, Ethopia, using SWAT model. Open Hydrol J 2:49-62

Sivapalan M, Ruprecht JK, Viney NR (1996a) Water and salt balance modeling to predict the effects of land use changes in forested catchments: 1. Small catchment water balance model. Hydrol Process 10:393-411

Sivapalan M, Viney NR, Ruprecht JK (1996b) Water and salt balance modeling to predict the effects of land use changes in forested catchments: 2. Coupled model of water and salt balances. Hydrol Process 10:413-428

Sivapalan M, Viney NR, Jeevaraj CG (1996c) Water and salt balance modeling to predict the effects of land use changes in forested catchments: 3. The large catchment model. Hydrol Process 10:429-446

Soil Conservation Service (SCS) (1965) Computer model for project formulation hydrology, Technical Release No. 20. USDA, Washington, DC

Srinivasan R, Arnold JG (1994) Integration of a basin scale water quality model with GIS. Water Resour Bull 30(3):453-462 
Srinivasan R, Arnold JG, Rosenthal W, Muttiah RS (1993) Hydrologic modeling of Texas Gulf Basin using GIS. In: Proceedings of 2nd International GIS and Environmental Modeling, Breckinridge, Colorado, pp.213-217

Srinivasan R, Ramanarayanan TS, Arnold JG, Bednarz ST (1998) Large area hydrologic modeling and assessment part II: model application. J Am Water Resour Assoc 34(1):91-101

Srinivasan R, Zhang X, Arnold J (2010) SWAT unguaged: Hydrological budget and crop yield prediction in the upper Mississipi river basin. ASABE 53(5):1533-1546

Suryavanshi S (2013) Long term prediction of hydro-meteorelogical variables in Betwa basin. Unpublished Ph.D. thesis Department of Water Resources Development and Management Indian Institute of Technology Roorkee India

Tennessee Valley Authority (1972) A continuous daily streamflow model: Upper Bear Creek, Experimental Project Research Paper No. 8, Knoxville, TN

Vazquez-Amábile GG, Engel BA (2005) Use of SWAT to compute groundwater table depth and streamflow in the Muscatatuck River watershed. Am Soc Agric Eng 48(3):991-1003

USDA (1980) CREAMS: A field scale model for chemicals, runoff and erosion from agricultural management systems. In: Knisel WG (ed) Conservation Research Report No. 26. US Department of Agriculture, Washington, DC

Williams JR (1995a) The EPIC model. In: Singh VP (ed) Computer models of watershed hydrology, chap 25. Water Resources Publications, Littleton, CO

Williams JR (1995b) SWRRB-A watershed scale model for soil and water resources management. In: Singh VP (ed) Computer models of watershed hydrology, chap 24. Water Resources Publications, Littleton, $\mathrm{CO}$
Williams JR, Jones CA, Dyke PT (1984) The EPIC model and its application. In: Proceedings of ICRISAT-IBSNAT-SYSS symposium on minimum data sets for agrotechnology transfer, pp 111-121

Willmot CJ (1981) On the validation of models. Phys Geogr 2:184-194

Young RA, Onstad CA, Bosch DD, Anderson WP (1989) AGNPS: a nonpoint source pollution model for evaluating agricultural watershed. J Soil Water Conserv 44:168-173

Young RA, Onstad CA, Bosch DD (1995) AGNPS: an agricultural nonpoint source model. In: Singh VP (ed) Computer models of watershed hydrology, chap 26. Water Resources Publications, Littleton, $\mathrm{CO}$

Yu Z, Schwartz FW (1998) Application of integrated basin-scale hydrologic model to simulate surface water and ground-water interactions in Big Darby Creek Watershed, Ohio. JAWRA 34:409-425

Yu Z, Lakhtakia MN, Yarnal B, White RA, Miller DA, Frakes B, Barron EJ, Duffy C, Schwartz FW (1999) Simulating the riverbasin response to atmospheric forcing by linking a mesoscale meteorological model and a hydrologic model system. J Hydrol 218:72-91

Zhang X, Srinivasan R, Van Liew M (2008) Multisite calibration of the SWAT model for hydrologic modeling. Trans ASABE 51(6):2039-2049

Zhang X (2009) Evaluating and developing parameter optimization and uncertainty analysis methods for a computationally intensive distributed hydrologic model. Ph. diss.Texas A\&M University, College Station 